\title{
The potential of endophytic bacteria from the root of Eucalyptus pellita as a biocontrol agent against Ralstonia solanacearum
}

\author{
YULIANA SUSANTI ${ }^{1,2}$, GIYANTO $^{1, \bullet}$, MEITY SURADJI SINAGA ${ }^{1}$, KIKIN HAMZAH MUTAQIN $^{1}$, \\ BUDI TJAHJONO ${ }^{2}$ \\ ${ }^{1}$ Department of Plant Protection, Faculty of Agriculture, Institut Pertanian Bogor. Jl. Raya Darmaga, Kampus IPB Darmaga, Bogor 16680, West \\ Java, Indonesia. Tel.: +62-251-8622642, `email: giyanto@apps.ipb.ac.id, yulianasusanti.upp@ gmail.com \\ ${ }^{2}$ Department of Plant Protection, Research and Development, PT. Arara Abadi Sinarmas Forestry. Jl. Minas-Perawang Km 26, Districts Siak Sri \\ Indrapura 28772, Riau, Indonesia
}

Manuscript received: 12 January 2021. Revision accepted: 29 May 2021.

\begin{abstract}
Susanti Y, Giyanto, Sinaga MS, Mutaqin KH, Tjahjono B. 2021. The potential of endophytic bacteria from the root of Eucalyptus pellita as a biocontrol agent against Ralstonia solanacearum. Biodiversitas 22: 3454-3462. Bacterial wilt disease (BWD) caused by Ralstonia solanacearum is one of the most damaging eucalyptus (Eucalyptus pellita F. Muell.) diseases. However, endophytic bacteria can be utilized to control it. This study aims to obtain and screen endophytic bacteria isolated from the root of eucalyptus as a biocontrol agent against BWD. A pathogenic $R$. solanacearum was isolated for artificial inoculation; subsequently, isolation, characterization and screening of the potential endophytic bacteria were conducted. Isolates of $R$. solanacearum demonstrated the pathogenicity for BWD in eucalyptus, with the highest virulence found in Rs 18. In total, 24 isolates of endophytic bacteria were obtained and screened for their biocontrol potential. The endophytic bacteria conveyed the capacity of antibiosis, indole acetic acid (IAA) hormone, nitrogen fixation, phosphate dissolution, protease enzyme and AHL-lactonase, which are the main indicators of bioagent characteristics in endophytic bacteria, as well as being plant growth stimulators. Four isolates were selected with the highest according to the analytic hierarchy process (AHP), identified on the 16S rRNA gene. Most isolates belonged to gram-negative bacteria. The four isolates, namely B33/77 (Serratia nematodiphila), B32/77 (Paenibacillus polymyxa), B13/497 (Brevundimonas olei) and B17/111 (Bacillus megaterium), indicated their potential for biocontrol as plant growth promoters. This study is the first report on the isolation of endophytic bacterial from eucalyptus roots with regard to its benefit as a plant growth promoter. It provides basic information about the characteristics of the endophytic bacteria, which showed potential as a biocontrol agent of $R$. solanacearum on eucalyptus.
\end{abstract}

Keywords: Characteristics, endophytic bacteria, Eucalyptus pellita, identification

\section{INTRODUCTION}

In Indonesia, eucalyptus is the second main industrial timber commodity (or HTI in Indonesia) after acacia. The type of eucalyptus that is predominantly planted is Eucalyptus pellita F. Muell, due to its suitability as a raw material for the pulp and paper industries. E. pellita is also an alternative to Acacia mangium, which is currently exhibiting high mortality due to root fungi disease (Ganoderma philippii, Phellinus noxius, Rigidoporus microporus) (Yuskianti et al. 2013). Moreover, E. pellita has also shown excellent results in terms of its fast growth, straight boles/trunks, good coppice capability, wide adaptation range to various environmental conditions, robustness against pests and disease, and as it is suitable for various wood products (Hung et al. 2015).

The industrial forest of $\log$ production was mainly supplied from six tree species, one of which is eucalyptus. After acacia, eucalyptus has the second-highest log production, contributing $19.58 \%$ of the total national timber for $\log$ production, or 40,628.78 $\mathrm{m}^{3} /$ year 2018 (BPS 2019). However, the productivity of eucalyptus silviculture has declined recently due to disease, one of the most widespread being bacterial wilt disease (BWD). This is caused by Ralstonia solanacearum, which is also the main pathogen in annual crops. BWD caused by $R$. solanacearum in woody perennial plants has only been recorded only in the eucalyptus species. However, BWD has spread significantly to major eucalyptus-producing countries in Africa, Asia, and America (Ran et al. 2005).

Bacterial wilt disease had caused vast damage in concession areas of the industrial forest. The first incident of BWD in Indonesia was reported by Machmud (1985). An outbreak in a lowland eucalyptus plantation in Jambi was also reported in 2006, which spread to plantations in Riau, Palembang and East Borneo. Siregar et al. (2012) report that the losses caused by BWD during the period 2010-2011 in Riau, from incidences in nurseries affecting the planting blocks, totaled 16 billion rupiahs.

Bacteria $R$. solanacearum infection in eucalyptus could spread from nurseries, even if no wilt symptoms are yet evident. The disease can then progress through the planting fields, triggered by silviculture stresses, in which the infected plants exhibit yellowing leaves, followed by wilting. Incisions on infected stems show an elongated necrotic symptom. When a cut on an infected stem is immersed in clear water, milky white bacterial fluid will ooze out (Coutinho and Wingfield 2017). The wilting 
progresses rapidly in the infected plant because the xylem vessels are blocked by exopolysaccharide (EPS) from the bacterial cells, thus disturbing water and nutrient transport. The virulent cells of the bacteria produce large amounts of EPS (Arwiyanto 2014).

Efforts to control BWD have been made through various approaches; e.g., eradication, using synthetic chemicals; selection of resistant eucalyptus; multi-clone planning; molecular early detection of BWD in nurseries to ensure the planting stock is BWD free; and use of biological agents. However, those efforts have not yet shown effective results. Several attempts to control BWD in eucalyptus have been reported in research (Santiago et al. 2015; Nuri et al. 2016; Asril et al. 2020). Recent reports on $R$. solanacearum show that infection takes place not only through the roots, but also occurs through the eucalyptus seeds (Siregar et al. 2020), and that it has high genetic diversity and a wide host. This will make controlling BWD even more difficult. Nevertheless, efforts continue to develop, one of which is the biocontrol technique using endophytic bacteria.

Endophytic bacteria as a biocontrol agent have advantages over other bioagents due to their presence in plant tissues, thus readily adapting to the familiar environment conditions in order to survive biotic and abiotic stresses (Hong and Park 2016). They are able to colonize the plant tissues where the $R$. solanacearum develops. Moreover, endophytic bacteria could reduce or prevent the negative effects of particular pathogen organisms. The mechanism of endophytic bacteria in controlling pathogens in the host plant occurs directly and indirectly. In the direct mechanism, the bacteria enhance the nutrient (phosphate, nitrogen, iron) uptake and increase the plant hormones (auxin, ethylene, cytokinin, gibberellin). On the other hand, the indirect mechanism involves antibiosis, lytic enzyme, nutrient competition, and defense induction (Afzal et al. 2019). Due to the alarming incidents that have occurred in the industrial forest eucalyptus in Indonesia, it was considered necessary to conduct research to obtain potential endophytic bacteria to control BWD, thus maintaining and enhancing the productivity of the eucalyptus plantations.

\section{MATERIALS AND METHODS}

\section{Collection of healthy and bacterial wilt disease-infected eucalyptus}

To isolate pathogenic $R$. solanacearum, purposive sampling of roots was conducted in the eucalyptus plantation of PT. Arara Abadi Perawang, Riau, on 1-2 year old plants. Root samples from healthy plants were collected from five susceptible clones and one commercial/resistant clone from six plots in the area where eucalyptus was planted. In addition, plant samples infected with BWD were taken from five clones of susceptible plants from five plots. The roots collected from healthy and infected plants were kept in labelled plastic bags and transferred to the laboratory for further isolation processes. The infected plant samples were then isolated to obtain the virulent $R$. solanacearum isolate, while isolates of endophytic bacteria were isolated from the healthy plant samples.

\section{Isolation of $R$. solanacearum, physiology test and pathogen identification}

The pathogen was isolated from the stem of an $R$. solanacearum infected plant. A crosswise-cut stem showing BWD symptoms was immersed in sterile water for 2-3 minutes. Whitish bacterial ooze exuded from the stem into the water. From the water in which the stem was soaked, $1 \mathrm{~mL}$ were taken and put into a reaction tube, then $9 \mathrm{~mL}$ sterile water added. The bacteria suspension was serial-diluted to $10^{-3}$ and cultured in a modification of media triphenyl tetrazolium chloride (TZC), a combination of nutrient agar (NA) medium with potato sucrose agar (PSA), known as NAPSA medium (modified by the R\&D PT. Arara Abadi). The cultures were incubated at room temperature for 48 hours. The composition of NAPSA medium was $3 \mathrm{~g}$ beef extract, $2.5 \mathrm{~g}$ glucose. $5 \mathrm{~g}$ peptone, $20 \mathrm{~g}$ sucrose, $100 \mathrm{~g}$ potato extract, $20 \mathrm{~g}$ agar, and $1000 \mathrm{~mL}$ water, with $4 \mathrm{~mL}$ TZC added after the medium had been sterilized. The identification of $R$. solanacearum isolate was made by morphology (the shape and color of the bacterial colony) and a physiology test (hypersensitive response, fermentative oxidative, potato soft root, levan), following the method of Schaad (2001). Molecular identification was based on the Y2/Oli-1 (Ashmawy 2015) and 16S rRNA gene (Jiang et al. 2006). A pathogenicity test was performed by the wound inoculation technique on the roots of eucalyptus seedlings (Fonseca et al. 2015).

\section{Isolation of endophytic bacteria}

Isolation of the endophytic bacteria was conducted in accordance with method of Hallmann et al. (1997). A root sample of eucalyptus was surface-sterilized by washing it under running water and it was cut with sterile scalpel into $1-2 \mathrm{~cm}$ pieces $10 \mathrm{~g}$ of the root was then soaked in $70 \%$ alcohol for two minutes, immersed in NaOCI $1 \%$ for two minutes, and then rinsed three times with sterile water. The root cuts were then dried with sterile tissue. The success of the surface sterilization was tested by rubbing the root cut on NA and tryptone soya agar (TSA) medium and incubated for two days. Sterilization was deemed successful if there were no bacteria detected growing in the medium. The sterilized roots were macerated using a blender until fine with the addition of sterile water 1:10 $(\mathrm{v} / \mathrm{v}) .1 \mathrm{~mL}$ of the bacteria suspension was taken and serially diluted to $10^{-3}$ dilution. From each dilution, $0.1 \mathrm{~mL}$ of suspension was cultured on TSA $10 \%$ and NA $10 \%$ media, and incubated for 48 hours. The growth of the colony was observed for two days. Each detected colony with different morphologies was then purified in the NA medium.

\section{Filtering of endophytic bacteria isolates as a bioagent Test of hypersensitivity reaction $(H R)$}

An HR test was performed on 173 isolates of endophytic bacteria isolated from the eucalyptus root. An isolate of endophytic bacteria was cultured in a nutrient broth (NB) medium for 12 hours in a shaking incubator at a speed of $120 \mathrm{rpm}$. $2 \mathrm{~mL}$ of bacteria suspension was 
infiltrated on the abaxial side of a tobacco leaf, thus wetting the cell inter-spaces. An observation was made 48 hours after the application. Positive reactions were denoted by the emergence of necrotic symptoms on the inoculated leaf, while negative reactions were signified by no occurrence of necrosis. Necrotic symptoms indicate the pathogenic potential of endophytic bacteria on plants (Schaad et al. 2001). Isolates of bacteria with positive reactions were not used in further tests.

\section{Test of hemolysis}

This test aimed to differentiate endophytic bacteria isolated from the tissue of eucalyptus based on the capability of lysis red blood cells, which indicate its potential as a mammal pathogen. An isolate of endophytic bacteria was cultured in a blood agar medium and incubated at room temperature for 18-24 hours. The occurrence of a clear zone around the colony indicated the potential of the isolates as a pathogen for humans and animals (Zimbro et al. 2009). Isolates that showed clear zones in the test were not used in further tests.

\section{Test of pathogenicity on eucalyptus seedlings}

The eucalyptus seedlings used in the test originated from shoot cuttings. These were surface sterilized with Clorox $0.5 \%$ for 1 minute and rinsed three times with sterile water. The cuttings were then soaked in $150 \mathrm{~mL}$ of the suspension of endophytic bacteria isolated for six hours (Paz et al. 2012). The control plant was treated by soaking it only in sterile water. The shoot cuttings were planted in a pot tray containing a sterile cocopeat medium. Observation for BWD symptoms was conducted three months after planting. Endophytic bacteria that caused symptoms of necrosis, decay, wilting, collapse, and mortality were not used in further tests.

\section{Growth promoter test on eucalyptus seedlings}

The preparation of eucalyptus seedlings and the inoculation of endophytic bacteria isolate followed the pathogenicity test protocol. The growth parameters measured were stem height and diameter. Endophytic bacteria isolate that caused less growth than the control treatment was not chosen for further analysis.

\section{Characterization of endophytic bacteria to determine potential isolates for biocontrol \\ Antibiosis capacity}

Analysis of the antibiosis capacity of endophytic bacteria on $R$. solanacearum was made in accordance with the cross-streak method (Velho-Pereira and Kamat 2011). The isolate of $R$. solanacearum used for the analysis was BWD 18, which had already been identified as showing the highest virulency. The isolates of endophytic bacteria were cultured in an NA medium and the isolates of $R$. solanacearum were cultured in a NAPSA medium for 48 hours. A loop of $R$. solanacearum was put into $10 \mathrm{~mL}$ of sterile water $\left(10^{8} \mathrm{cfu} \mathrm{mL}^{-1}\right)$ and subsequently vortexed. From the $R$. solanacearum suspension, $0.1 \mathrm{~mL}$ was spread using a glass beat on the NAPSA medium in petri disc. In addition, endophytic bacteria were scratched vertically on the NAPSA medium. The treatment was replicated 3 times. Antibiosis activity was denoted by the formation of a clear zone around the endophytic bacteria colony.

\section{Protease production}

Endophytic bacteria were cultured in skim milk agar (SMA) media. The media composition was $25 \mathrm{~g}$ skim milk, $20 \mathrm{~g}$ agar and $1000 \mathrm{~mL}$ water. The formation of a clear zone around the colony of endophytic bacteria denoted the activity of the bacteria in producing protease enzyme (Hazra and Susanti 2017).

\section{Production of indole acetic acid (IAA)}

The IAA production of the endophytic bacteria was analyzed with a colorimeter, using a Salkowski reagent (150 mL concentrated $\mathrm{H}_{2} \mathrm{SO}_{4} ; 7.5 \mathrm{~mL} \mathrm{FeCl} 3.6 \mathrm{H}_{2} \mathrm{O} 0.5 \mathrm{M}$; $250 \mathrm{~mL}$ sterile water). A loop of 48-hour old endophytic bacteria was inoculated on the NB medium. After 24 hours, $500 \mu \mathrm{lL}$ of the bacteria culture was then inoculated in 50 $\mathrm{mL}$ of the NB medium, which contained $0.1 \%$ DLtryptophan, and incubated in a shaker at $180 \mathrm{rpm}$ for 48 hours in dark conditions. It was then centrifuged at 10,000 $\mathrm{rpm}$ and $4{ }^{\circ} \mathrm{C}$ for 10 minutes. The resulting supernatant IAA was then estimated with the colorimetry method. $1 \mathrm{~mL}$ of the supernatant was prepared and then mixed with $4 \mathrm{~mL}$ of Salkowski reagent. When the supernatant turned pink after 30 minutes, the absorbance was then observed with a spectrophotometer at a wavelength of $535 \mathrm{~nm}$. The pinkcolored supernatant conveyed the production of IAA (Ghevariya and Desai 2014).

\section{Phosphate dissolving}

The capability of endophytic bacteria to dissolve phosphate was analyzed in a Pikovskaya medium test. The composition of the medium was glucose $10 \mathrm{~g} ; \mathrm{Ca}_{3}\left(\mathrm{PO}_{4}\right)_{2} 5$ g; $\left(\mathrm{NH}_{4}\right)_{2} \mathrm{SO}_{4} 0.5 \mathrm{~g} ; \mathrm{NaCl} 0.2 \mathrm{~g} ; \mathrm{MgSO}_{4} .7 \mathrm{H}_{2} \mathrm{O} 0.1 \mathrm{~g} ; \mathrm{KCl}$ $0.1 \mathrm{~g}$; yeast extract $0.5 \mathrm{~g} ; \mathrm{MnSO}_{4} 0.5 \mathrm{~g} ; \mathrm{FeSO}_{4} 0.5 \mathrm{~g}$; agar $15 \mathrm{~g}$; and $1000 \mathrm{~mL}$ water at $\mathrm{pH}$ 7. The cultures of endophytic bacteria were grown overnight in an NB medium. Subsequently, the bacteria were scratched onto the Pikovskaya medium and incubated for 4 days in room temperature. The presence of a clear zone around the bacteria colony indicated the capability of endophytic bacteria to dissolve phosphate (Ghevariya and Desai 2014).

\section{Nitrogen fixation}

Analysis of nitrogen fixation was made in a semi-solid nitrogen-free medium. The medium composition was DLmalic acid $5 \mathrm{~g}, \mathrm{~K}_{2} \mathrm{HPO}_{4} 0.5 \mathrm{~g}, \mathrm{MgSO}_{4} .7 \mathrm{H}_{2} \mathrm{O} 0.2 \mathrm{~g}, \mathrm{CaCl}_{2}$ $0.02 \mathrm{~g}, \mathrm{NaCl} 0.1 \mathrm{~g}, \mathrm{FeSO}_{4} \cdot 7 \mathrm{H}_{2} \mathrm{O} 0.5 \mathrm{~g}, \mathrm{Na}_{2} \mathrm{MoO}_{4} \cdot 2 \mathrm{H}_{2} \mathrm{O} 2$ $\mathrm{mg}, \mathrm{MnSO}_{4} \cdot \mathrm{H}_{2} \mathrm{O} 10 \mathrm{mg}, 0.5 \%$ bromothymol blue in $0.2 \mathrm{~N}$ KOH- $2 \mathrm{~mL}, 1.64 \%$ FeEDTA solvent $4 \mathrm{~mL}$, agar $2 \mathrm{~g}$, and $1000 \mathrm{~mL}$ water at $\mathrm{pH}$ 6.8. Endophytic bacteria were incubated for 5 days at $30{ }^{\circ} \mathrm{C}$. The bacteria colonies with evidence of a thin layer (pellicle) were considered positive as a nitrogen fixer (Ghevariya and Desai 2014).

\section{Detection of AHL-lactonase molecularly}

The detection of gene coding AHL-lactonase was initiated by extracting the total DNA of the endophytic 
bacteria using a DNA extraction kit (Geneaid blood and cultured cells). The amplification of lactonase genes was performed using a specific primer that was aiiA1 forward (5'-ATGACAGTAAARAARCTTTATTTC-3') and aiiA2 reverse (5'-TCACTATATATAYTCMGGGAACTC-3), with a $753 \mathrm{pb}$ target size (Pan et al. 2008). The PCR cocktail with a total volume of $25 \mu \mathrm{L}$ consisted of $5 \mu \mathrm{L}$ PCR buffer $5 \mathrm{x} ; 0.5 \mu \mathrm{L}$ dNTP $10 \mathrm{mM} ; 2.5 \mu \mathrm{L} \mathrm{MgCl} 25$ $\mathrm{Mm} ; 0.25 \mu \mathrm{L}$ Taq polymerase $5 \mu \mathrm{L}$, each of primer forward and reverse was $0.1 \mu \mathrm{L}$; template DNA $4 \mu \mathrm{L}$ and water $12.55 \mu \mathrm{L}$. The PCR was conducted using a 2720 Thermal Cycler Applied Biosystem machine, with a PCR program that covered pre-denaturation at $94{ }^{\circ} \mathrm{C}$ for 5 minutes, followed by 30 cycles of denaturation at $94{ }^{\circ} \mathrm{C}$ for 1 minute, annealing at $55^{\circ} \mathrm{C}$ for 1.5 minutes, extension at $72{ }^{\circ} \mathrm{C}$ for 2 minutes, and with a final extension at $72{ }^{\circ} \mathrm{C}$ for 5 minutes. Loading electrophoresis of the total volume of the PCR results was made in agarose $1 \%$. The PCR results of the bacteria isolates that formed an amplicon with a designated size indicated the capacity of the bacteria to produce AHL lactonase.

\section{Selection of potential endophytic bacteria isolate}

The results of the endophytic bacteria characterization, which included antibiosis capacity, protease enzyme production, IAA, phosphate dissolving, nitrogen fixation and AHL lactonase, were further analyzed using the analytic hierarchy process (AHP) method, in accordance with Saaty (2008). The chosen bacteria were those with the highest scores, ranked 1-4.

\section{Identification of endophytic bacteria based on the $16 \mathrm{~S}$ rRNA gene}

The four chosen isolates of endophytic bacteria based on the results of the AHP analysis were then further identified molecularly. Extraction of the total DNA of the endophytic bacteria was performed using a DNA extraction kit (Geneaid blood and cultured cells). The isolated DNA was then amplified using a bacteria universal primer consisting of primer forward $27 \mathrm{~F} 5$ AGAGTTTGATCCTGG CTCAG-3' and primer reverse 1492R 5'-GGTTACCTTGTTACGACTT-3', with a target $16 \mathrm{~S}$ rRNA gene which was approximately $1500 \mathrm{pb}$ in size (Jiang et al. 2006). The resulting PCR products were subsequently sent for sequencing to paid analytic institution, First Base (Selangor, Malaysia). Sequent analysis was conducted following several steps: editing sequents with the Bioedit program, and construction of a phylogeny tree using the Mega X program.

\section{RESULTS AND DISCUSSION}

\section{Characterization of pathogenic bacteria}

The identification of bacteria isolates collected from eucalyptus with BWD symptoms showed similar morphology traits to $R$. solanacearum bacterium. The isolates reacted positively in fermentative-oxidative, hypersensitive and potato soft rot tests. On the other hand, the isolate reacted negatively in gram, stain, and levan tests. Colony of isolates bacteria, milky white in color, with fluidal pinkish colony center in the NAPSA media. Five pathogenic bacteria isolates were collected from five eucalyptus clones. Molecular detection on isolates Rs 10, Rs 15, Rs 16, Rs 18, and Rs 19 showed DNA amplicons matched the pathogen $R$. solanacearum species complex (RSSC) and electrophoretic visualization showed amplified of the Oli-1/Y2 primer pair resulting in DNA bands with a length of $288 \mathrm{pb}$. Alignment of the sequence DNA fragments generated from PCR with BLAST using $16 \mathrm{~S}$ rRNA primers showed the results of the bacterial species Ralstonia solanacearum (Table 1).

The results of the confirmation on the pathogen bacteria based on sequencing of the 16S rRNA gene showed similarities with $R$. solanacearum. Bacteria $R$. solanacearum has a high diversity of genotypes and phenotypes, and is thus called the $R$. solanacearum species complex (RSSC). The results of the virulency test showed that isolate Rs 18 caused the highest level of wilting in the eucalyptus seedlings, reaching $90 \%$, with average latent period of 6.6 days. Even though the pathogen isolates used was the same, the virulency levels and pathogen malignancy causing disease symptoms on the plants were diverse. Based on the results, isolate Rs 18 was used for further analysis.

\section{Endophytic bacteria morpho-physiological characteristics}

Total bacteria that were isolated successfully from the eucalyptus root comprised 173 isolates. Of these, 24 passed the screening for the bioagent safety test. The screening results are shown in Table 2.

Table 2. Screening of endophytic bacteria isolated from eucalyptus for Ralstonia solanacearum bioagent

\begin{tabular}{lcccc}
\hline \multirow{2}{*}{$\begin{array}{l}\text { Bioagent safety } \\
\text { test }\end{array}$} & \multicolumn{4}{c}{ Screening of endophytic bacteria } \\
\cline { 2 - 5 } & $\begin{array}{c}\text { Number of } \\
\text { bacteria }\end{array}$ & $\begin{array}{c}\text { Reactive } \\
\text { reaction }\end{array}$ & $\begin{array}{c}\text { Positive } \\
\text { reaction }\end{array}$ & $\begin{array}{c}\text { Negative } \\
\text { reaction }\end{array}$ \\
\hline HR Test & 173 & 83 & 83 & 90 \\
Hemolysis test & 90 & 48 & 48 & 42 \\
Pathogenicity test & 42 & 8 & 8 & 34 \\
Growth test & 34 & 10 & 10 & 24 \\
\hline
\end{tabular}

Table 1. Alignment results and virulence level of Ralstonia solanaceraum isolate based on sequencing of the 16S rRNA gene

\begin{tabular}{|c|c|c|c|c|c|c|c|}
\hline \multirow[b]{2}{*}{$\begin{array}{c}\text { Host } \\
\text { eucalyptus }\end{array}$} & \multirow[b]{2}{*}{$\begin{array}{l}\text { Isolate } \\
\text { code }\end{array}$} & \multirow[b]{2}{*}{$\begin{array}{c}\text { Accession } \\
\text { number }\end{array}$} & \multicolumn{2}{|c|}{ Homolog with sequencing of GenBank } & \multirow[b]{2}{*}{$\begin{array}{c}\text { Homology } \\
(\%)\end{array}$} & \multicolumn{2}{|c|}{ Virulency test } \\
\hline & & & Species & $\begin{array}{c}\text { Query cover } \\
(\%)\end{array}$ & & $\begin{array}{c}\text { Incidence } \\
(\%)\end{array}$ & $\begin{array}{c}\text { Average incubation } \\
\text { period (days) }\end{array}$ \\
\hline Clone ep A & Rs 10 & CP052129 & $R$. solanacearum & 99 & 99.28 & 60 & 8.2 \\
\hline Clone ep B & Rs 15 & MT367730 & R. solanacearum & 100 & 99.64 & 60 & 13.8 \\
\hline Clone ep C & Rs 16 & MK825301 & R. solanacearum & 99 & 98.74 & 80 & 8.6 \\
\hline Clone ep D & Rs 18 & KP017467 & R. solanacearum & 99 & 98.26 & 90 & 6.6 \\
\hline Clone ep E & Rs 19 & MT367730 & R. solanacearum & 100 & 99.71 & 50 & 8.2 \\
\hline
\end{tabular}


An HR test was designated as the preselection method to determine whether or not the bacteria were pathogenic on plants. Necrotic symptoms on the tobacco leaves indicated the pathogenicity of the endophytic bacteria. A reactive reaction was denoted by necrotic symptoms, while no apparent necrosis indicated a negative reaction. HR will take place in plants as a response to pathogen infection (Balint-Kurti 2019). Moreover, it is essential to ensure the safe use of the endophytic bacteria in the environment, especially in relation to mammals. The capability of the endophytic bacteria lysis erythrocytes would classify the endophytic bacteria as a mammal pathogen or show a positive reaction (Suardana et al. 2014).

Even though the endophytic bacteria passed the HR selection, this did not fully demonstrate the pathogenicity and bioagent capacity of the endophytic bacteria for all plant species, as there are other bacteria that are pathogenic to tobacco; for example, Pseudomonas syringae (Krzymowska et al. 2007). Therefore, further analysis was required; for instance, a pathogenicity test and bacteria impact on plant growth. In the pathogenicity test, a negative reaction was represented by a $100 \%$ plant survival rate. On the contrary, a positive reaction was indicated by disease symptoms (e.g. wilt, necrosis, stunted growth, rotting, and collapse with survival rate of less than $100 \%$. Growth analysis of the eucalyptus seedlings was made to ensure that the endophytic bacteria did not impede growth, even though it showed no signs of pathogenicity. Screening of all the isolated endophytic bacteria isolates through HR, hemolysis, pathogenicity and a growth test resulted in 24 candidate isolates of endophytic bacteria from the eucalyptus root (Table 2).

The selected endophytic bacteria were then macroscopically characterized and analyzed in a Gram test. The morphology of the endophytic bacteria was observed based on color, shape of the top and edge, elevation, and surface of the colony. Analysis of the colony's morphology and of the Gram test showed diversity amongst the isolates, and after the results of the growth and AHP analysis, several isolates displayed apparent potential species of endophytic bacteria (Table 3). These selected potential species were then subsequently identified.

\section{Endophytic bacteria as biocontrol agents and plant growth promoters}

Analysis of the characteristics and capacity as plant growth promoters was made on the 24 screened isolates. The characterization resulted in 18 isolates with antibiosis capacity, nine with IAA hormone, nine as nitrogen fixers, 14 with phosphate dissolving capacity, 15 with protease enzyme and nine with AHL lactonase (Figure 1).

\section{Selection of potential isolates based on the Analytic Hierarchy Process (AHP) and 16S rRNA analysis}

The AHP method selected endophytic bacteria that exhibited excellence in several previously conducted tests. The results from these tests on the 24 isolates were tabulated and scored in terms of the excellence of each isolate. From this method, isolates with the highest scores were then chosen, namely B33/77, B32/77, B13/497, and B17/111 (Table 4).

The selected isolates of endophytic bacteria based on the AHP method were then molecularly identified. Homology analysis revealed that isolates B33/77, B32/77, B13/497 and B17/111 had the highest nucleotide homolog, at 91.62 - $99.63 \%$ for Serratia nemadophila (MN691588), Paenibacillus polymyxa (KF439806), Brevundimonas olei (MT341805), and Bacillus megaterium (CP049296). The endophytic bacteria were identified using BLAST and compared to similar bacteria in the NCBI GenBank. When the homology is close to $100 \%$ or above $97 \%$ (Table 4), it can be confirmed as the same species. On the contrary, if the homology is less than $97 \%$, then the species could be an entirely new or unconfirmed one (Vetrovsky and Baldrian 2013).

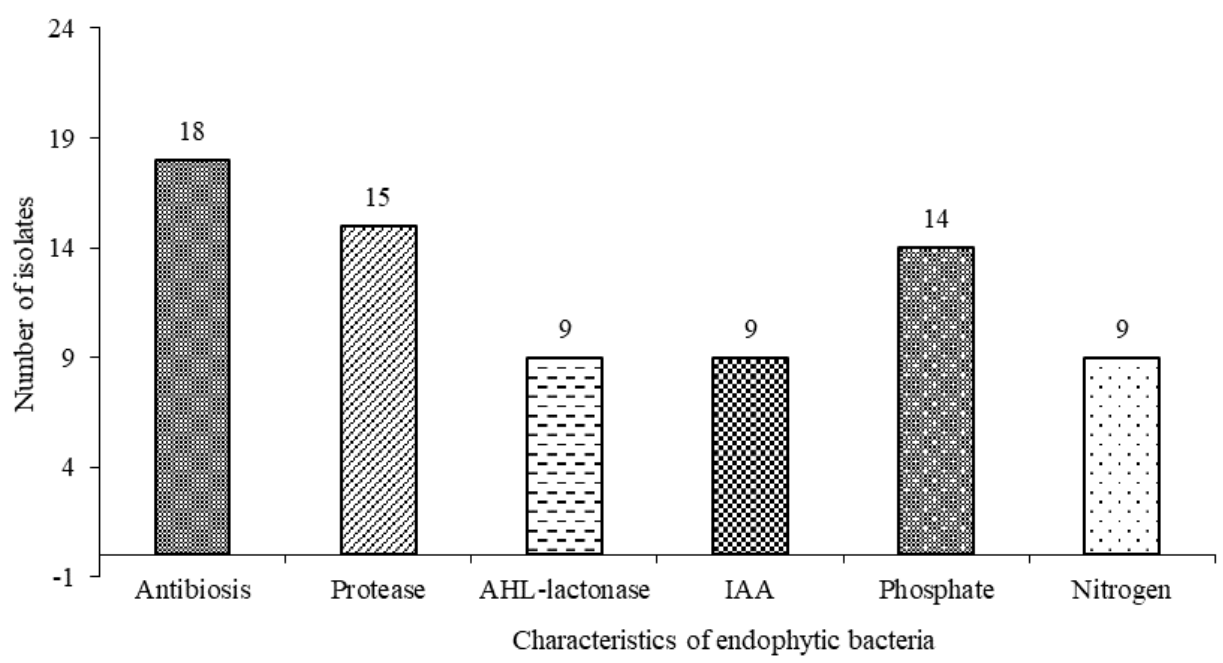

Figure 1. Characteristics of endophytic bacteria as bioagents and plant growth promoters 
Table 3. General characteristics of endophytic bacteria from the eucalyptus root

\begin{tabular}{|c|c|c|c|c|c|c|}
\hline \multirow{2}{*}{ Isolate code } & \multirow{2}{*}{ Color } & \multicolumn{2}{|c|}{ Shape of } & \multirow{2}{*}{ Elevation } & \multirow{2}{*}{ Surface } & \multirow{2}{*}{ Gram } \\
\hline & & Colony form & Margin & & & \\
\hline B19/497 & White & Round & Entire & Convex & Glistening & Positive \\
\hline B8/497 & Beige & Round & Rhizoid & Umbonate & Not glistening & Negative \\
\hline B30/497 & Beige & Round & Entire & Umbonate & Glistening & Negative \\
\hline B13/497 & White & Round & Entire & Umbonate & Not glistening & Negative \\
\hline B4/497 & Beige & Round & Entire & Umbonate & Glistening & Negative \\
\hline B32/77 & White & Round-Concentric & Filamentous & Convex & Glistening & Positive \\
\hline B1/77 & White & Round & Entire & Convex & Glistening & Positive \\
\hline B34/77 & White & Round & Entire & Convex & Glistening & Negative \\
\hline B36/77 & White & Round & Entire & Convex & Not glistening & Positive \\
\hline B33/77 & White & Round & Lobate & Umbonate & Glistening & Negative \\
\hline $\mathrm{B} 15 / 77$ & White & Round & Rhizoid & Umbonate & Not glistening & Negative \\
\hline B37/77 & White & Round-Concentric & Rhizoid & Raised & Glistening & Positive \\
\hline B20/77 & Beige & Round & Entire & Convex & Glistening & Negative \\
\hline B3/5147 & White & Filamentous & Filamentous & Umbonate & Glistening & Positive \\
\hline B37/5147 & White & Round-Concentric & Filamentous & Umbonate & Not glistening & Negative \\
\hline B15/5147 & Beige & Round & Lobate & Convex & Glistening & Positive \\
\hline B14a/5147 & Beige & Round & Entire & Plat & Glistening & Negative \\
\hline B25/5147 & White & Round & Entire & Umbonate & Glistening & Positive \\
\hline B14/5147 & Beige & Round & Entire & Umbonate & Glistening & Positive \\
\hline B17/111 & White & Round & Entire & Raised & Glistening & Negative \\
\hline B15/111 & Milky white & Irregular & Irregular & Convex & Glistening & Positive \\
\hline B4/111 & White & Round & Lobate & Convex & Glistening & Negative \\
\hline B22/111 & White & Round-Concentric & Lobate & Raised & Glistening & Negative \\
\hline B13/111 & White & Round & Irregular & Umbonate & Not glistening & Positive \\
\hline
\end{tabular}

Table 4. Scoring of endophytic bacteria based on excellence from several tests

\begin{tabular}{|c|c|c|c|c|c|c|c|c|c|c|c|c|}
\hline \multirow{2}{*}{$\begin{array}{l}\text { Isolate } \\
\text { code }\end{array}$} & \multicolumn{6}{|c|}{ Criteria } & \multirow{2}{*}{$\begin{array}{l}\text { Result of } \\
\text { AHP } \\
\text { analysis }\end{array}$} & \multirow{2}{*}{ Rank } & \multicolumn{4}{|c|}{$\begin{array}{l}\text { Identification of the endophytic bacteria isolates based on the } \\
16 \mathrm{~S} \text { rRNA gene }\end{array}$} \\
\hline & $\mathbf{A}$ & $\mathbf{B}$ & $\mathbf{C}$ & D & $\mathbf{E}$ & $\mathbf{F}$ & & & Accession & Species & $\begin{array}{l}\text { Query } \\
\text { cover }(\%)\end{array}$ & $\begin{array}{l}\text { Identity } \\
(\%)\end{array}$ \\
\hline B33/77 & 4 & 3 & 2 & 1 & 1 & 1 & 0.3264 & 1 & MN691588 & atodiphila & 100 & 98.45 \\
\hline B17/111 & 3 & 1 & 1 & 2 & 1 & 2 & 0.3139 & 2 & СР049296 & Bacillus megaterium & 100 & 91.62 \\
\hline B13/497 & 3 & 1 & 2 & 2 & 1 & 2 & 0.3133 & 3 & MT341805 & Brevundimonas olei & 99 & 98.42 \\
\hline B32/77 & 3 & 2 & 1 & 3 & 1 & 1 & 0.2853 & 4 & KF439806 & Paenibacillus polymyxa & 100 & 99.63 \\
\hline
\end{tabular}

Note: Antibiosis (A), Protease (B), Phosphate (C), IAA (D), Nitrogen (E), AHL lactonase (F)

\section{Discussion}

Eucalyptus plants infected with BWD in the field showed symptoms of partial to complete wilting, starting with yellowing and finally drying of the leaves. Eucalyptus stems that are attacked will turn blackish in color (discoloration). If this part of the plant is cut, it will become brown rot vertically. If the stems or branches of the plant are attacked, and are then cut and left for a while, they will release a milky white liquid, which is a bacterial colony. According to Ferreira et al. (2017) and Coutinho and Wingfield (2017), eucalyptus plants infected with BWD show symptoms of wilting; yellowing of the leaves, which fall and leave bare plant stems without leaves; and when the stems are cut, the color of the xylem is changed and bacterial fluid is secreted. If the symptoms are severe, the tree will easily collapse due to infection and a defective root system. The results of the isolation of disease causes in eucalyptus show the same morphological and physiological characteristics as $R$. solanacearum (Schaad et al. 2001). The results of molecular pathogen identification also show the same species as $R$. solanacearum species complex (RSSC). This proves that the pathogenic bacteria used in this study are $R$. solanacearum isolates, which are the cause of BWD in eucalyptus in the concession area of PT. Arara Abadi in Perawang, Riau.

The results of the isolation of endophytic bacteria from the eucalyptus roots obtained 24 isolates that passed the biosafety test. These bacteria had different morphological characteristics, which showed their diversity in the roots of eucalyptus plants. Endophytic bacteria can be isolated from all plant organs, such as leaves, roots, stems and fruit (Firdous et al. 2019), and one plant can acquire different types of them (Gaiero et al. 2013). In addition, they have different physiological characteristics, such as Gram bacteria. There are several endophytic bacteria that are Gram-negative and positive. In general, Gram-positive bacteria have a cell wall layer that is thicker than the Gramnegative type, while Gram-negative bacteria contain a higher percentage of lipids than positive olnes (Wulandari et al. 2012). Although in this study most of the endophytic 
bacteria obtained were Gram-negative, some were proven to be biological agents against plant pathogens, such as Brevundimonas olei, which can inhibit the development of Fusarium wilt disease in tomato plants (Islam et al. 2019).

Endophytic bacterial isolates from eucalyptus showed characteristics of antibiosis ability, protease enzymes, AHL lactonase, IAA hormone, phosphate solvent, and nitrogenfixing. These characteristics have the potential to trigger plant growth and can suppress the development of plant diseases. Eighteen isolates showed antibiosis activity (Figure 1). The majority of endophytic bacteria produce various types of antibiotics, such as ecomycins, pseudomycins, and kakadumycins, which have an antibacterial function against pathogens (Singh et al. 2017). The endophytic bacteria Bacillus amyloliquefaciens has been shown to be antagonistic against various plant pathogenic bacteria, namely $R$. solanacearum, Pseudomonas syringae, and Xanthomonas campestris, and has been shown to be effective in biological control of Capsicum bacterial wilt in pot and field experiments (Hu et al. 2010). In addition, antibiosis-producing endophytic bacteria can act as an inducing agent (elicitor) for plant resistance to disease (Fadiji and Babalola 2020).

Fifteen endophytic bacteria isolated from the eucalyptus plants showed the capability to produce protease enzyme (Figure 1). Protease is a proteolytic enzyme that catalyzes the breaking down of peptide bonds in protein into simpler molecules (Rori et al. 2020). Bacteria with protease enzyme can hydrolyze casein and break down the peptide bonds of the pathogenic bacteria. The enzyme breaks protein down into peptides and amino acids, which are utilized for the growth of the bacteria. The endophytic bacteria with protease enzyme can also protect the roots of tomato and chili from $R$. solanacearum infection (Amaresan et al. 2012). Some endophytic bacteria, e.g. Pseudomonas, Burkholderia, Bacillus, Serratia, and Paenibacillus, acknowledged for their secondary metabolites, including antibiotic and extracellular enzymes, have shown the ability to fight plant pathogens (Khan et al. 2017).

The characteristic of endophytic bacteria of producing the AHL lactonase enzyme can prevent pathogenic bacterial infections in plants. Such bacteria from eucalyptus have the ability to produce the enzyme. Virulence factors of plant pathogenic bacteria are toxins, enzymes and exopolysaccharides (Prasannath 2013). The expression of virulence factors of plant pathogenic bacteria is controlled by the quorum sensing (QS) mechanism. Efforts that can be used to inhibit QS include the use of endophytic bacteria which produce the enzyme AHL lactonase. This enzyme can degrade and inactivate the QS signaling molecule. The mechanism of plant disease control using AHL-lactonaseproducing bacteria has been widely reported, such as $R$. solanacearum (Achari and Ramesh 2015). 3-hydroxy palmitic acid methyl ester (3OH-PAME) is a QS molecule that regulates virulence factor expression in $R$. solanacearum. Stenotrophomonas maltophilia, Pseudomonas aeruginosa, Rhodococcus corynebacterioides are able to degrade $3 \mathrm{OH}-\mathrm{PAME}$, thereby reducing the expression of virulence factors (exopolysaccharides and endoglucanase) from $R$. solanacearum in vitro and reducing the incidence of wilt in eggplant seedlings in greenhouses (Achari and Ramesh 2015). In this study, nine isolates showed endophytic bacteria with the AHL lactonase enzyme.

Endophytic bacteria with the characteristic of Indole-3acetic acid (IAA) production play a role in nutrient absorption and promote plant growth; nine isolates exhibited this trait (Figure 1). IAA is the main auxin in plants that is involved in various physiological processes, such as cell signaling, regulation of plant development, and the induction of defense systems (Fu et al. 2015). The bacteria can promote plant growth through the synthesis of IAA, cytokinin and gibberellin hormones, or through the regulation of hormone internal level in plants. IAA produced by endophytic bacteria within plants can increase the number of lateral and adventive roots, thus betterfacilitating nutrient access and improving root exudation, which in turn will enhance the height and biomass of the plant (Kandel et al. 2017; Olatunji et al. 2017; Guan et al. 2019). Auxin is involved in various aspects of plant growth and development. It also plays a role as a microbesignaling molecule, directly influencing the biology of several pathogens (Kunkel and Harper 2018).

The phosphate-dissolving character of endophytic bacteria supports plants' nutrient provision. Phosphorous (P) is an essential micronutrient involved in enzymatic reaction and is accountable in most plant physiological processes (Ahemad 2014). P is the second mineral nutrient after nitrogen $(\mathrm{N})$ that often limits plant growth. The average soil $\mathrm{P}$ is around $0.05 \%$, but the available $\mathrm{P}$ that can be utilized by plants is only $0.1 \%$ of that finite amount (Alori et al. 2017). Endophytic bacteria can increase the available $\mathrm{P}$ by dissolving precipitated phosphates through mechanisms such as oxidation, chelation, ion exchange and organic acid production (Walia et al. 2017). This study found fourteen isolates of endophytic bacteria with the phosphate-dissolving characteristic (Figure 1).

The ability of endophytic bacteria to fix nitrogen can help provide macronutrients for plants. Nitrogen is an essential macronutrient because it is a component of proteins and enzymes, the nucleic acids that make up DNA, and chlorophyll, which makes the photosynthesis process in plants possible. In the atmosphere, much of the nitrogen is in an unavailable form (N2), which cannot be used by plants. In order for plants to use N2, nitrogen must be fixed in the form of nitrate (NO3-) and ammonium (NH4 +) (Doty 2017; Puri et al. 2018). Endophytic bacteria can supply nitrogen from the atmosphere to their host plants by expressing nitrogenase activity. Most of the genera of endophytic bacteria, including Achromobacter, Azoarcus, Burkholderia, Enterobacter, Gluconoacetobacter, Herbaspirillum, Klebsiella and Serratia, have been reported to increase plant growth due to their ability to fix nitrogen (Hallmann et al. 1997). Some endophytic bacteria have nitrogen fixation (nifH gene) and denitrification genes. The Paenibacillus polymyxa $\mathrm{P} 2 \mathrm{~b}-2 \mathrm{R}$ isolates obtained from lodgepole pine tissue was able to colonize the rhizosphere and endosphere niches of maize plants and encourage their growth (Liu et al. 2017). Only nine isolates from this study showed this $\mathrm{N}$ fixation capacity (Figure 1). 
The filtering, characterization, selection and identification of the endophytic bacteria based on the sequence of the 16S rRNA gene from the eucalyptus resulted in Serratia nematodiphila, Paenibacillus polymyxa, Brevundimonas olei, and Bacillus megaterium species. The collected isolates of $S$. nematodiphila showed antibiosis, protease enzyme, phosphate dissolving and nitrogen fixation capacity, while $P$. polymyxa showed characteristics of antibiosis, protease enzyme and IAA hormone. B. olei revealed traits of antibiosis, phosphate dissolving, IAA hormone, nitrogen fixation and AHL lactonase enzyme, while the isolates of $B$. megaterium exhibited capacity for antibiosis, IAA hormone and AHL lactonase enzyme. The results of this study are in accordance with previous ones that have reported these species of endophytic bacteria as bioagents to control plant diseases (Timmusk et al. 2019; Soenens and Imperial 2020; Vasconez et al. 2020).

Therefore, endophytic bacteria collected from eucalyptus plants showed significant potential as biocontrol agents against BWD in eucalyptus both in nurseries and fields. The collected endophytic bacteria that have already been successfully characterized could be further explored for other plant disease controlling mechanisms; for example, to attest the defense induction, plant growth promoter and pathogen suppression mechanisms.

\section{ACKNOWLEDGEMENTS}

The authors would like to thank the Directorate General of Higher Education (Dirjen DIKTI) for funding this research through the scholarship of BPPDN (23965/E4.4/2015) and Doctoral Dissertation Research Grant (0045/E3/LL/2018). We are also grateful to the Department of Research and Development of PT. Arara Abadi Sinarmas Forestry, Perawang, Riau, Indonesia.

\section{REFERENCES}

Achari GA, Ramesh R. 2015. Characterization of bacteria degrading 3 hydroxy palmitic acid methyl ester (3OH-PAME), a quorum-sensing molecule of Ralstonia solanacearum. Appl Microbiol 60: 447-455. DOI: 10.1111/lam.12389.

Afzal I, Shinwari ZK, Sikandar S, Shahzad S. 2019. Plant beneficial endophytic bacteria: Mechanisms, diversity, host range and genetic determinants. Microbiol Res 221: 36-49. DOI: 10.1016/j.micres.2019.02.001.

Ahemad M. 2014. Phosphate-solubilizing bacteria-assisted phytoremediation of metalliferous soils: a review. 3 Biotech 5: 111121. DOI: $10.1007 / \mathrm{s} 13205-014-0206-0$.

Alori ET, Glick BR, Babalola OO. 2017. Microbial Phosphorus solubilization and its potential for use in sustainable agriculture. Front Microbiol 8 (971): 1-8. DOI: 10.3389/fmicb.2017.00971.

Amaresan N, Jayakumar V, Kumar K, Thajuddin N, Nadu T, Islands N, Division CP. 2012. Endophytic bacteria from tomato and chilli, their diversity and antagonistic potential against Ralstonia solanacearum. Arch Phytopathol Plant Protect 45 (3): 37-41. DOI: 10.1080/03235408.2011.587273.

Arwiyanto T. 2014. Ralstonia solanacearum, Biologi, Penyakit yang Ditimbulkan dan Pengelolaannya. Gadjah Mada University Press, Yogyakarta. [Indonesian]

Asril M, Lisafitri Y, Siregar BA. 2019. A possibility of proteolytic bacteria utilization to control Ralstonia solanacearum 59 In Vitro. In:
International Conference on Science, Infrastructure Technology and Regional Development. Earth Environ Sci 537, Lampung, 25-26 October 2019. DOI: 10.1088/1755-1315/537/1/012040 [Indonesian]

Ashmawy NA. 2015. Detection and molecular characterization of some Egyptian isolates of Ralstonia solanacearum by Nested-PCR and PCR-RFLP Analyses. Plant Pathol J 14 (4): 168-174. DOI: 10.3923/ppj.2015.168.174.

Balint-Kurti P. 2019. The plant hypersensitive response : concepts, control and consequences. Mol Plant Pathol 20 (8): 1163-1178. DOI: 10.1111/mpp. 12821.

[BPS] Badan Pusat Statistik. 2019. Statistik Perusahaan Pembudidaya Tanaman Kehutanan 2018. Badan Pusat Statistika, Jakarta. [Indonesian]

Coutinho TA, Wingfield MJ. 2017. Ralstonia solanacearum and $R$. Pseudosolanacearum on eucalyptus: Opportunists or primary pathogens?. Front Plant Sci 8: 1-7. DOI: 10.3389/fpls.2017.00761.

Doty LS. 2017. Endophytic N-Fixation: Controversy and a Path Forward. In: Doty SL (eds) Functional Importance of the Plant Microbiome. Springer International Publishing AG, Seattle. DOI: 10.1007/978-3319-65897-1_2.

Fadiji AE, Babalola OO. 2020. Elucidating mechanisms of endophytes used in plant protection and other bioactivities with multifunctional prospects. Front Bioeng Biotechnol 8 (467): 1-20. DOI: 10.3389/fbioe.2020.00467

Ferreira MA, Mafia RG, Alfenas AC. 2017. Ralstonia solanacearum decreases volumetric growth of trees and yield of kraft cellulose of Eucalyptus spp. For Pathol 48 (1): 1-5. DOI: 10.1111/efp.12376

Firdous J, Lathif NA, Mona R, Muhamad N. 2019. Endophytic bacteria and their potential application in agriculture: A review. Indian J Agric Res 53 (1): 1-7.

Fonseca NR, Oliveira LSS, Guimaraes LMS, Teixeira RU, Lopes CA, Alfenas AC. 2015. An efficient inoculation method of Ralstonia solanacearum to test wilt resistance in Eucalyptus spp. Trop Plant Pathol 41 (1): 42-47. DOI: 10.1007/s40858-015-0056-2.

Fu S, Wei J, Chen H, Liu Y, Lu H, Chou J. 2015. Indole-3-acetic acid : A widespread physiological code in interactions of fungi with other organisms. Plant Signaling Behav 10 (8): 1-9. DOI: 10.1080/15592324.2015.1048052.

Gaiero JR, McCall CA, Thompson KA, Day NJ, Best AS, Dunfield KE. 2013. Inside the root microbiome: bacterial root endophytes and plant growth promotion. Am J Bot 100 (9): 1738-1750. DOI: 10.3732/ajb.1200572.

Ghevariya K, Desai P. 2014. Rhizobacteria of sugarcane: In vitro screening for their plant Growth Promoting potentials. Res J Recent Sci 3: 52-58.

Guan L, Tayengwa R, Cheng ZM, Peer WA, Murphy AS. 2019. Auxin regulates adventitious root formation in tomato cuttings. BMC Plant Biol 19 (435): 1-16. DOI: 10.1186/s12870-019-2002-9.

Hallmann J, Quadt-Hallmann A, Mahaffee WF, Kloepper JW. 1997. Bacterial endophytes in agricultural crops. Can J Microbiol 43 (10): 895-914. DOI: 10.1139/m97-131.

Hazra F, Susanti WI. 2017. Buku Panduan Praktikum Bioteknologi tanah. IPB Press, Bogor. [Indonesian]

Hong CE, Park JM. 2016. Endophytic bacteria as biocontrol agents against plant pathogens: current state-of-the-art. Plant Biotechnol Rep 10 (6): 353-357. DOI: 10.1007/s11816-016-0423-6.

Hu HQ, Li XS, He H. 2010. Characterization of an antimicrobial material from a newly isolated Bacillus amyloliquefaciens from mangrove for biocontrol of Capsicum bacterial wilt. Biol Control 54 (3): 359-365. DOI: 10.1016/j.biocontrol.2010.06.015.

Hung TD, Brawner JT, Meder R, Lee DJ, Southerton S, Thinh HH, Dieters MJ. 2015. Estimates of genetic parameters for growth and wood properties in Eucalyptus pellita F. Muell. to support tree breeding in Vietnam. Ann For Sci 72 (2): 205-217. DOI: 10.1007/s13595-014-0426-9.

Islam A, Kabir S, Khair A. 2019. Molecular identification and evaluation of indigenous bacterial isolates for their plant growth-promoting and biological control activities against Fusarium wilt pathogen of tomato. Plant Pathol J 35 (2): 137-148. DOI: 10.5423/PPJ.OA.06.2018.0104.

Jiang H, Dong H, Zhang G, Chapman LR, Fields MW, Jiang H, Dong H, Zhang G, Yu B, Chapman LR, Fields MW. 2006. Microbial Diversity in Water and Sediment of Lake Chaka, an Athalassohaline Lake in Northwestern China. Appl Environ Microbiol 72 (6): 3832-2845. DOI: 10.1128/AEM.02869-05. 
Kandel SL, Joubert PM, Doty SL. 2017. Bacterial endophyte colonization and distribution within plants. Microorganisms 5 (77): 1-26. DOI: 10.3390/microorganisms5040077.

Khan AL, Shahzad R, Al-harrasi A, Lee IJ. 2017. A Resource for Producing Extracellular Enzymes. In: Maheshwari DK, Annapurna K (eds) Endophytes: Crop Productivity and Protection, Sustainable Development and Biodiversity. Springer International Publishing AG, New York. DOI: 10.1007/978-3-319-66544-3 5.

Krzymowska M, Konopka-postupolska D, Sobczak M, Macioszek V, Ellis BE. 2007. Infection of tobacco with different Pseudomonas syringae pathovars leads to distinct morphotypes of programmed cell death. He Plant J 50: 253-264. DOI: 10.1111/j.1365-313X.2007.03046.x.

Kunkel BN, Harper CP. 2018. The roles of auxin during interactions between bacterial plant pathogens and their hosts. J Exp Bot 69 (2): 245-254. DOI: 10.1093/jxb/erx447.

Liu H, Carvalhais LC, Crawford M, Singh E, Dennis PG, Pieterse CMJ, Schenk PM. 2017. Inner Plant Values: Diversity, Colonization and Benefits from Endophytic Bacteria. Front Microbiol 8 (2552): 1-17. DOI: 10.3389/fmicb.2017.02552

Machmud M. 1985. Bacterial wilt in Indonesia. In: Craswell ET, Pushperajah E (eds) Bacterial Wilt Disease in Asia and The South Pacific. ACIAR, Canberra.

Nuri P, Siregar BA, Surtinah, Lidar S. 2016. Pengujian bakteriofage virulen terhadap patogen Ralstonia solanacearum penyebab penyakit layu bakteri pada tanaman eukaliptus (Eucalyptus pellita). In: Joko T, Wibowo A, Suryanti, Widiastuti A, Sulandari S, Hartono S, Indarti S, Wirianata H, Soelistijono, Hadiwiyono, Setyawan B, Martosupono M (eds) Pengendalian Penyakit Tanaman Pertanian Ramah Lingkungan II; Prosiding Seminar Nasional. Universitas Gadjah Mada, Yogyakarta, 27 Agustus 2016. [Indonesian]

Olatunji D, Geelen D, Verstraeten I. 2017. Control of endogenous auxin levels in plant root development. Int J Mol Sci 18 (2587): 1-29. DOI 10.3390/ijms 18122587.

Pan J, Huang T, Yao F, Huang Z, Powell CA, Qiu S, Guan X. 2008. Expression and characterization of aiiA gene from Bacillus subtilis BS-1. Microbiol Res 163 (6): 711-716. DOI: 10.1016/j.micres.2007.12.002.

Paz IC, Santin RC, Guimaraes AM, Rosa OP, Dias AC, Quecine MC, Azevedo JL, Matsumura AT. 2012. Eucalyptus growth promotion by endophytic Bacillus spp. Genet Mol Res 11 (4): 3711-3720. DOI: 10.4238/2012.August.17.9.

Prasannath K. 2013. Review article pathogenicity and virulence factors of phytobacteria. Scholars Acad J Biosci 1 (1): 24-33.

Puri A, Padda KP, Chanway CP. 2018. Nitrogen-Fixation by Endophytic Bacteria in Agricultural Crops: Recent Advances. In: Khan A, Fahad $\mathrm{S}$ (eds) Nitrogen in Agriculture. In Tech, Serang. DOI: 10.5772/intechopen.71988

Ran L, Liu C, Wu G, VanLoon L, Bakker P. 2005. Suppression of bacterial wilt in Eucalyptus urophylla by fluorescent Pseudomonas spp. in China. Biol Control 32 (1): 111-120. DOI 10.1016/j.biocontrol.2004.08.007.

Rori CA, Ester F, Kandou F, Tangapo AM. 2020. Aktivitas enzim ekstraseluler dari bakteri endofit tumbuhan mangrove Avicennia marina. Jurnal. Bios Logios 10 (2): 48-55. DOI: 10.35799/jbl.11.2.2020.28338 [Indonesian]

Saaty TL. 2008. Decision-making with the analytic hierarchy process. Int J Serv Sci 1 (1): 83-98. DOI: 10.1504/IJSSCI.2008.017590.
Santiago TR, Grabowski C, Rossato M, Romeiro RS, Mizubuti ESG. 2015. Biological control of eucalyptus bacterial wilt with rhizobacteria. Biol Control 80: 14-22. DOI: 10.1016/j.biocontrol.2014.09.007.

Schaad NW. 2001. Initial Identification of Common Genera. In: Schaad NW, Jones JB, Chun W (eds) Laboratory Guide for Identification of Plant Pathogenic Bacteria. APS Press, St. Paul.

Singh M, Kumar A, Singh R, Pandey KD. 2017. Endophytic bacteria: a new source of bioactive compounds. 3 Biotech 7 (315): 1-14. DOI: 10.1007/s13205-017-0942-Z

Siregar BA, Indrayadi H, Mardai. 2012. Ancaman Penyakit layu bakteri terhadap produktivitas Eucalyptus pellita di dataran rendah tropis. In: Laporan Tahunan R\&D PT. Arara Abadi. Perawang: R\&D PT. Arara Abadi. [Indonesian]

Siregar BA, Gafur A, Nuri P, Halimah H, Tjahjono B, Golani GD. 2020. First report on infection of Eucalyptus pellita seeds by Ralstonia solanacearum. Environ Sci Proceedings 3 (94): 1-4. DOI: 10.3390/IECF2020-07904.

Soenens A, Imperial J. 2020. Biocontrol capabilities of the genus Serratia. Phytochem Rev 19 (3): 577-587. DOI: 10.1007/s11101-019-09657-5.

Suardana IW, Utama IH, Wibowo H. 2014. Identifikasi escherichia coli o157:h7 dari feses ayam dan uji profil hemolisisnya pada media agar darah. Jurnal Kedokteran Hewan 8 (1): 1-5. DOI: 10.21157/j.ked.hewan.v8i1.1236 [Indonesian]

Timmusk S, Copolovici D, Copolovic L, Tede T, Nevo E, Behers L. 2019. Paenibacillus polymyxa biofilm polysaccharides antagonise Fusarium graminearum. Sci Rep 9 (662): 1-11. DOI: 10.1038/s41598-01837718-w.

Vasconez RDA, Moya EMT, Yepez LAC, Chiluisa-Utreras VP, Suquillo Ide los AV. 2020. Evaluation of Bacillus megaterium strain AB4 as a potential biocontrol agent of Alternaria japonica, a mycopathogen of Brassica oleracea var. italica. Biotechnol Rep J 26: 1-6. DOI: 10.1016/j.btre.2020.e00454

Velho-Pereira S, Kamat NM. 2011. Antimicrobial screening of actinobacteria using a modified cross-streak method. Indian J Pharm Sci 73 (2): 223-228. DOI: 10.4103/0250-474X.91566.

Vetrovsky T, Baldrian P. 2013. The variability of the 16S rRNA gene in bacterial genomes and its consequences for bacterial community analyses. PLoS One 8 (2): 1-10. DOI: 10.1371/journal.pone.0057923.

Walia A, Guleria S, Chauhan A, Mehta P. 2017. Endophytic bacteria: Role in phosphate solubilization. In: Maheshwari DK, Annapurna K (eds) Endophytes: Crop Productivity and Protection, Sustainable Development and Biodiversity. Springer Nature Switzerland AG, Swiss. DOI: 10.1007/978-3-319-66544-3_4.

Wulandari H, Zakiatulyaqin, Supriyanto. 2012. Isolasi dan pengujian bakteri ebdofit dari tanaman lada (Piper nigrum L.) sebagai antagonis terhadap patogen hawar beludru (Septobasidium sp.). Jurnal Perkebunan dan Lahan Tropika 2 (2): 23-31. [Indonesian]

Yuskianti V, Glen M, Puspitasari D, Francis A, Agustini L, Rimbawanto A, Mohammed C. 2013. Molecular identification of root-rot diseases in Acacia mangium and Eucalyptus pellita plantations in Indonesia. In: International Conference of Indonesia Forestry Researcher (INAFOR) Forest Health In A Changing World. Forestry Research And Development Agency, Bogor, 27-28 August 2013. [Indonesian]

Zimbro MJ, Power DA, Miller SM, Wilson GE, Johnson JA. 2009. Difco and BBL Manual: Manual of Microbiological Culture Media. Becton. Dickinson and Company, Maryland. 